\title{
Lactic acid bacteria of the Leuconostoc genus with high innate immunity-stimulating activity
}

\author{
Masaki Ishii ${ }^{1}$, Satoshi Nishida ${ }^{1,2}$, Keiko Kataoka ${ }^{1}$, Yayoi Nishiyama ${ }^{3}$, Shigeru Abe ${ }^{3}$, \\ Kazuhisa Sekimizu ${ }^{1,3, *}$ \\ ${ }^{1}$ Genome pharmaceuticals institute Co. Ltd., Tokyo, Japan; \\ ${ }^{2}$ Department of Microbiology and Immunology, Teikyo University School of Medicine, Tokyo, Japan; \\ ${ }^{3}$ Teikyo University Institute of Medical Mycology, Tokyo, Japan.
}

\begin{abstract}
Summary We screened lactic acid bacteria that exhibited high innate immunity-stimulating activity by monitoring muscle contraction activity in silkworms. Heat-treated fractions of lactic acid bacteria, Leuconostoc carnosum \#7-2, Leuconostoc gelidum \#4-2, and Leuconostoc mesenteroides 8/11-3, had high (250-460 units/mg) innate immunity-stimulating activity. These lactic acid bacteria proliferated in milk to concentrations of $1 \times 10^{6}$ colony forming unit/mL. The present findings suggest that the silkworm muscle contraction assay is useful for screening lactic acid bacteria with high innate immunity-stimulating activity, and that the assay can be used for the production of fermented foods made from milk.
\end{abstract}

Keywords: Lactic acid bacteria, Leuconostoc sp., silkworm, innate immunity

\section{Introduction}

Lactic acid bacteria produce lactic acid and are used for the production of various fermented foods, such as yogurt and kimchi (Korean pickles). Lactic acid bacteria are considered effective for the treatment of diarrhea and regulation of immune responses (1-3). An established method to efficiently isolate lactic acid bacteria that are beneficial for human health would be useful for the development of foods containing functional lactic acid bacteria.

"Innate immunity-stimulating activity" is now recognized as an important function of lactic acid bacteria. Innate immunity, which does not involve antibodies, is the front line defense system in all animals and plants. In mammals, various stimuli promote the secretion of cytokines from immunocompetent cells such as macrophages, and induce the transmission of signals to other immunocompetent cells, followed by

Released online in J-STAGE as advance publication February 14, 2017.

*Address correspondence to:

Dr. Kazuhisa Sekimizu, Teikyo University Institute of Medical Mycology. 359 Ohtuka, Hachioji, Tokyo, 192-0395, Japan.

E-mail: sekimizu@main.teikyo-u.ac.jp the production of specific antibodies that eliminate pathogens. In invertebrate animals, such as insects, which do not possess acquired immunity, elimination of pathogens relies solely on innate immunity. The innate immune systems in insects and mammals have many common features. For example, cells called hemocytes ingest invasive foreign pathogens as well as macrophages in mammals (4). Moreover, Tolllike receptors, which are related to the innate immune response in mammals, have high homology with Toll receptors, which function in innate immune responses in Drosophila melanogaster (5). We previously reported that stimulation of the innate immune system activates a cytokine called paralytic peptide in silkworms, resulting in muscle contraction. This means that muscle contraction is coupled with the activation of innate immunity in silkworms. We established a simple method for measuring innate immunity-stimulating activity in various samples using this system (6). We demonstrated by monitoring muscle contraction ability in mouse macrophages that purified polysaccharides from green tea stimulate the production of cytokines (7). Using this system, we also demonstrated that certain species of lactic acid bacteria exhibit relatively high innate immunity-stimulating activity (8). Here we describe that three strains of lactic acid bacteria of the genus Leuconostoc isolated from kimchi and rice bran 
have high innate immunity-stimulating activity.

\section{Materials and Methods}

\subsection{Isolation and identification of lactic acid bacteria}

Samples obtained from kimchi and rice bran were streaked on deMan, Rogosa and Sharpe (MRS) agar (Becton, Dickinson and Company, MD, USA) plates containing $0.5 \%$ calcium carbonate (Wako Pure Chemical Industries, Osaka, Japan). After incubation at $30^{\circ} \mathrm{C}$ under anaerobic conditions, bacterial colonies with transparent halos were isolated and further characterized. The bacterial colonies were cultured in $15 \mathrm{~mL}$ of MRS broth (Becton, Dickinson and Company) under anaerobic conditions at $30^{\circ} \mathrm{C}$. Bacterial pellets were collected by centrifugation, suspended into $0.9 \% \mathrm{NaCl}$ (Wako Pure Chemical Industries), mixed well with the same volume of $80 \%$ glycerol (Wako Pure Chemical Industries), and stored at $-80^{\circ} \mathrm{C}$. The bacterial $16 \mathrm{~S}$ rDNA was amplified by colony polymerase chain reaction. A homology search was carried out on a database using BLAST. Bacterial species exhibiting the highest sequence homology were identified.

\subsection{Characterization of bacteria}

Gram staining was performed using Gram color (Merck, Kenilworth, NJ, USA). Bacteria were fixed by passing slides through the flame of a Bunsen burner. For scanning electron microscopy (SEM), bacterial cells were pre-fixed with $2.5 \%$ glutaraldehyde (POLYSCIENCES, INC., Warrington, PA, USA) in $0.1 \mathrm{M}$ cacodylate (TAAB, England) buffer ( $\mathrm{pH} 7.2$ ), post-fixed with $1 \%$ osmium tetroxide (Merck) in the same buffer, and freeze-dried in t-butyl alcohol (Wako Pure Chemical Industries). The samples were examined with field-emission SEM (JSM- 7500F, JEOL, Japan). The carbohydrate metabolism of each strain was determined using an Api $50 \mathrm{CH}$ system (SYSMEX bioMérieux Co., Ltd., Tokyo, Japan) by the following procedure. The lactic acid bacterial colonies were suspended and adjusted to match a McFarland turbidity standard of 2. One hundred-fifty microliters of the bacterial suspension was added to the Api plate, which was incubated at $30^{\circ} \mathrm{C}$ for $48 \mathrm{~h}$, and then carbohydrate metabolism was determined based on the color change. The catalase activity of each strain was determined by suspending the bacterial colonies in 3\% hydrogen peroxide (Wako Pure Chemical Industries). Other enzyme activities were determined using an Api Zym system (SYSMEX bioMérieux Co., Ltd., Tokyo, Japan).

2.3. Measurement of innate immunity-stimulating activity of lactic acid bacteria using silkworm muscle specimens
IHC was performed on 4- $\mu \mathrm{m}$ sections that had been $\mathrm{e}$ Innate immunity-stimulating activities of lactic acid bacteria were determined by measuring silkworm muscle contraction (6). Lactic acid bacterial suspensions cultured in $100 \mathrm{~mL}$ of MRS were autoclaved at $121^{\circ} \mathrm{C}$ for $20 \mathrm{~min}$, and the cells were collected by centrifugation at $8,000 \mathrm{rpm}$ at $4^{\circ} \mathrm{C}$. After washing with $50 \mathrm{ml}$ of $0.9 \% \mathrm{NaCl}$, the pellet was suspended in $1 \mathrm{~mL}$ of $0.9 \% \mathrm{NaCl}$. Fifty microliters of diluted suspension was injected into silkworm muscle specimens, and the length of the silkworm muscle specimens was measured $10 \mathrm{~min}$ after the injection. One unit of activity was defined as a sample dose that decreased the length of silkworm muscle specimens by $15 \%(6)$. Dry weights of the samples were determined after evaporation to calculate the specific activity.

\subsection{Growth test of lactic acid bacteria in milk}

Glycerol stocks $(1 \mu \mathrm{L})$ of lactic acid bacteria were added to $50 \mathrm{~mL}$ of milk (Meiji Co., Ltd., Japan), and cultured under anaerobic conditions at $30^{\circ} \mathrm{C}$ for 1 day. The number of viable cells in the milk was determined after spreading diluted samples on MRS agar plates and anaerobically culturing them at $30^{\circ} \mathrm{C}$ for $20 \mathrm{~h}$.

\section{Results}

\subsection{Isolation of lactic acid bacteria with high innate immunity-stimulating activity}

We isolated lactic acid bacteria from kimchi and rice bran, popular fermented foods in Korea and Japan, on MRS agar containing $0.5 \%$ calcium carbonate. Colonies of lactic acid bacteria were identified by transparent halos, which indicate the production of lactic acid. Isolated lactic acid bacteria were cultured in MRS following by heat treatment at $121^{\circ} \mathrm{C}$ for $15 \mathrm{~min}$.

Muscle contraction was measured to evaluate the innate immunity-stimulating activity (6). Each bacterial suspension was injected into silkworm muscle specimens. The activity of most of the lactic acid bacteria was much lower than 50 units/mg, but three lactic acid bacteria, \#7-2, \#4-2, and 8/11-3, exhibited activities higher than 100 units/mg (Table 1).

\subsection{Characterization of the isolated lactic acid bacteria}

Species of the three strains of lactic acid bacteria, \#7-2, \#4-2, and 8/11-3, that exhibited high innate immunitystimulating activity in the silkworm muscle contraction assay were determined by sequencing their 16S rDNA. The results indicated that \#7-2, \#4-2, and 8/11-3 were Leuconostoc carnosum, Leuconostoc gelidum, and Leuconostoc mesenteroides, respectively. We recognized that the genus of all three strains with high innate immunity-stimulating activities were Leuconostoc 
Table 1. Species and innate immunity-stimulating activity of three bacterial strains isolated from fermented foods

\begin{tabular}{|c|c|c|c|c|}
\hline Strains & Origins & Species & Identity (\%) & Relative activity ${ }^{\text {a) }}$ (units/mg) \\
\hline$\# 7-2$ & Kimchi & Leuconostoc carnosum & 99 & $460 \pm 240(n=3)$ \\
\hline \#4-2 & Rice bran & Leuconostoc gelidum & 99 & $250 \pm 140(n=3)$ \\
\hline $8 / 11-3$ & Kimchi & Leuconostoc mesenteroides & 99 & $250 \pm 190(n=4)$ \\
\hline
\end{tabular}

One unit of activity was defined as the activity required to decrease the length of silkworm muscle specimens by $15 \%(6)$. Values were mean \pm standard deviation.

Table 2. Carbohydrate metabolism of the three lactic acid bacteria strains isolated from fermented food

\begin{tabular}{|c|c|c|c|}
\hline Items & $\# 7-2$ & \#4-2 & $8 / 11-3$ \\
\hline Control & - & - & - \\
\hline Glycerol & - & - & - \\
\hline Erythritol & - & - & - \\
\hline D-Arabinose & - & - & - \\
\hline L-Arabinose & - & + & + \\
\hline D-Ribose & + & + & + \\
\hline D-Xylose & - & + & + \\
\hline L-Xylose & - & - & - \\
\hline D-Adonitol & - & - & - \\
\hline Methyl- $\beta$-D-Xylopyranoside & - & - & - \\
\hline D-Galactose & + & + & + \\
\hline D-Glucose & + & + & + \\
\hline D-Fructose & + & + & + \\
\hline D-Mannose & + & + & + \\
\hline L-Solbose & - & - & - \\
\hline L-Rhamnose & - & - & - \\
\hline Dulcitol & - & - & - \\
\hline Inositol & - & - & - \\
\hline D-Mannitol & - & + & + \\
\hline D-Sorbitol & - & - & + \\
\hline Methyl- $\alpha$-D-Mannopyranoside & - & - & - \\
\hline Methyl- $\alpha$-D-Glucopyranoside & + & + & + \\
\hline N-Acetyl Glucosamide & + & + & + \\
\hline Amygdalin & + & + & + \\
\hline Arbutin & + & + & + \\
\hline Esculin ferric citrate & + & + & + \\
\hline Salicin & + & + & + \\
\hline D-Cellobiose & + & + & + \\
\hline D-Maltose & + & + & + \\
\hline D-Lactose & - & - & + \\
\hline D-Melibiose & + & + & + \\
\hline D-Sucrose & + & + & + \\
\hline D-Trehalose & + & + & + \\
\hline Inulin & - & - & - \\
\hline D-Melezitose & + & + & + \\
\hline D-Raffinose & + & - & + \\
\hline Starch & + & + & - \\
\hline Glycogen & - & - & - \\
\hline Xylitol & - & - & - \\
\hline Gentiobiose & + & + & + \\
\hline D-Turanose & + & + & + \\
\hline D-Lyxose & - & - & - \\
\hline D-Tagatose & + & + & + \\
\hline D-Fucose & - & - & - \\
\hline L-Fucose & - & - & - \\
\hline D-Arabitol & - & - & - \\
\hline L-Arabitol & - & - & - \\
\hline Gluconate & + & + & + \\
\hline 2 Keto Gluconate & - & + & - \\
\hline 5 Keto Gluconate & - & - & - \\
\hline
\end{tabular}

The carbohydrate metabolism capacity was determined by Api $50 \mathrm{CH}$ system. Lactic acid bacteria on agar plates was suspended in suspension medium, and the bacterial density was adjusted to a McFarland turbidity standard of 2 . One hundred-fifty microliters of the bacterial suspension was added to an Api plate and incubated at $30^{\circ} \mathrm{C}$ for $48 \mathrm{~h}$. The metabolism capacity for each carbohydrate was determined based on the color change.
Table 3. Enzymatic activities of three lactic acid bacteria strains isolated from fermented foods

\begin{tabular}{lccc}
\hline Items & $\# 7-2$ & $\# 4-2$ & $\# 8 / 11-3$ \\
\hline Catalase & - & - & - \\
Alkaline phosphatase & + & - & + \\
Esterase (C4) & + & + & + \\
Esterase lipase (C8) & + & + & + \\
Lipase (C14) & - & - & - \\
Leucine aminopeptidase & + & + & + \\
Valine aminopeptidase & - & - & - \\
Cysteine aminopeptidase & - & - & - \\
Trypsin & - & - & - \\
Chymotrypsin & - & + & - \\
Acid phosphatase & + & + & + \\
Phosphoamidase & + & + & + \\
$\alpha$-Galactosidase & - & - & + \\
$\beta$-Galactosidase & - & - & + \\
$\beta$-Glucuronidase & - & - & - \\
$\alpha$-Glucosidase & + & + & + \\
$\beta$-Glucosidase & - & + & + \\
$\beta$-Glucosaminidase & - & - & - \\
$\alpha$-Mannosidase & - & - & - \\
$\alpha$-Fucosidase & - & - & - \\
\hline
\end{tabular}

The catalase activity of each strain was determined by suspending the bacterial colony in 3\% hydrogen peroxide. Other enzyme activities were determined by Api Zym system. Lactic acid bacteria were suspended in suspension medium, and adjusted to a McFarland turbidity standard of 5 or 6 . Sixty-five microliters of the bacterial suspension was added to an Api plate and incubated at $37^{\circ} \mathrm{C}$ for $4.5 \mathrm{~h}$. After incubation, enzymatic activities were determined based on the color change.

(Table 1). Moreover, we examined the bacteria for Gram staining and in an electron micrograph. We also performed a carbohydrate metabolism test and an enzymatic activity test of these lactic acid bacteria (Tables 2 and 3, Figures 1 and 2). All three strains were Grampositive coccal bacteria (Figure 1). SEM confirmed that these lactic acid bacteria had a coccal shape and were arranged in pairs or short chains (Figure 2). Results of the carbohydrate metabolism test were consistent with the notion that these bacteria belong to the Leuconostoc genus. All three strains exhibited esterase (C4), esterase lipase (C8), leucine aminopeptidase, acid phosphatase, phosphoamidase, and $\alpha$-glucosidase activities. In addition, \#7-2 and 8/11-3 exhibited alkaline phosphatase activity, \#4-2 exhibited chymotrypsin activity, 8/11-3 exhibited $\alpha$-galactosidase and $\beta$-galactosidase activities, and \#4-2 and 8/11-3 exhibited $\beta$-glucosidase activity.

\subsection{Growth of lactic acid bacteria in milk}

Plant-origin lactic acid bacteria are generally considered 
A

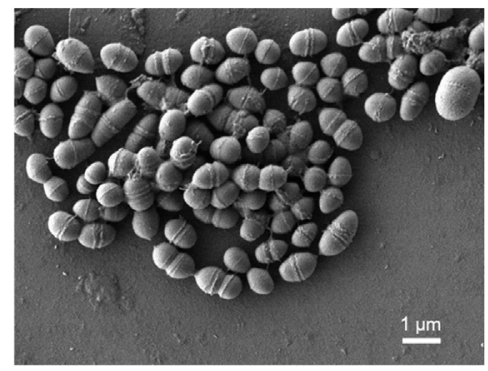

B

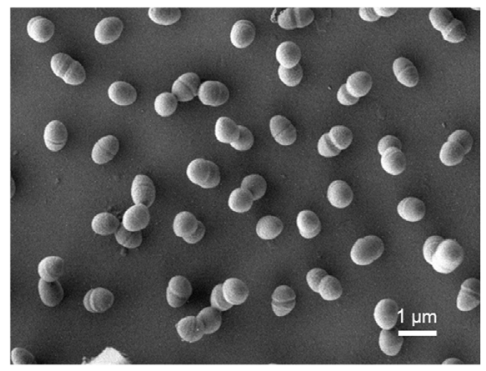

C

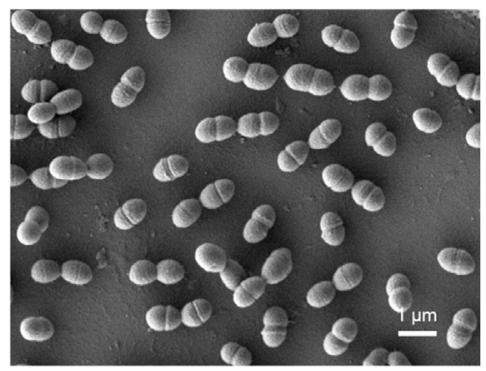

Figure 2. Scanning electron micrographs of lactic acid bacteria. Bacteria are shown at 10,000 $\times$ magnification. (A) Leuconostoc carnosum \#7-2, (B) Leuconostoc gelidum \#4-2, (C) Leuconostoc mesenteroides 8/11-03.
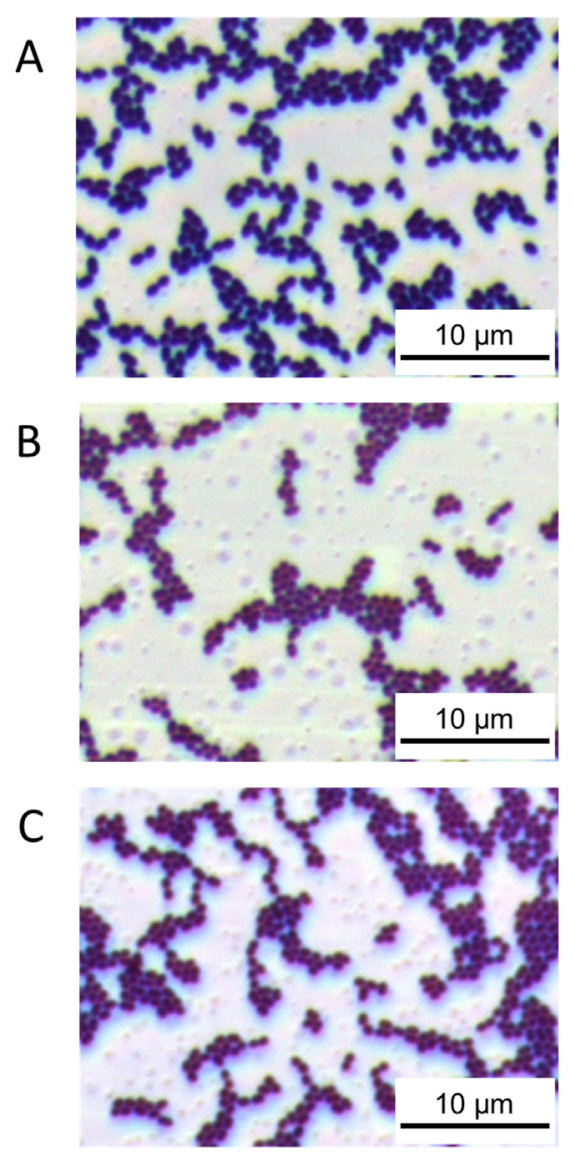

Figure 1. Gram stain of lactic acid bacteria. After Gram staining, bacteria cells were observed under an optical microscope at 1,000× magnification. (A) Leuconostoc carnosum \#7-2, (B) Leuconostoc gelidum \#4-2, (C) Leuconostoc mesenteroides 8/11-03.

Table 4. Growth of isolated lactic acid bacteria in milk

\begin{tabular}{lllcc}
\hline Strains & Origins & Species & Number of viable cells (before culture) & Number of viable cells (after culture) \\
\hline$\# 7-2$ & Kimchi & Leuconostoc carnosum & $9.0 \times 10^{5}(\mathrm{cells} / \mathrm{mL})$ & $3.4 \times 10^{6}(\mathrm{cells} / \mathrm{mL})$ \\
$\# 4-2$ & Rice bran & Leuconostoc gelidum & $<1.0 \times 10^{3}(\mathrm{cells} / \mathrm{mL})$ & $1.0 \times 10^{7}(\mathrm{cells} / \mathrm{mL})$ \\
$8 / 11-3$ & Kimchi & Leuconostoc mesenteroides & $4.6 \times 10^{4}(\mathrm{cells} / \mathrm{mL})$ & $1.0 \times 10^{8}(\mathrm{cells} / \mathrm{mL})$ \\
\hline
\end{tabular}

Glycerol stocks of lactic acid bacteria were added to $50 \mathrm{~mL}$ milk (Meiji Co., Ltd.) using a 1- $\mu \mathrm{L}$ disposable loop, and anaerobically cultured at $30^{\circ} \mathrm{C}$ for 1 day. The number of viable cells in the milk was calculated by counting the number of colonies that formed on MRS agar plates spread with $100 \mu \mathrm{L}$ of diluted milk and anaerobically cultured at $30^{\circ} \mathrm{C}$.

to be inappropriate for manufacturing yogurt as they lack the ability to grow in milk. Some plant-origin lactic acid bacteria, such as Lactococcus lactis, however, can grow in milk $(8,9)$. We examined whether the abovementioned lactic acid bacterial strains could grow in milk. Lactic acid bacteria were cultivated in milk at $30^{\circ} \mathrm{C}$ for $24 \mathrm{~h}$. Diluted samples were spread on agar plates, and the number of colonies was counted. The numbers of all three bacterial strains increased to more than $1.0 \times 10^{6}$ colony forming units $(\mathrm{cfu}) / \mathrm{mL}$ (Table 4$)$.

\section{Discussion}

In this paper, we describe three strains of lactic acid bacteria of the Leuconostoc genus, isolated from kimchi and rice bran, that exhibited high innate immunitystimulating activities as assessed by monitoring silkworm muscle contraction. Lactic acid bacteria of the Leuconostoc genus are used conventionally for manufacturing fermented foods, such as sauerkraut and kefir, which means that humans have experience eating these lactic acid bacteria. Recently, much attention has been focused on the use of lactic acid bacteria for maintaining good health. Establishment of methods for identifying functional lactic acid bacteria, however, are difficult. Our proposed method for measuring innate immunity-stimulating activity by silkworm muscle contraction is considered to be applicable for the 
discovery of lactic acid bacteria that have high innate immunity-stimulating activity.

Plant-origin lactic acid bacteria are considered suitable for manufacturing kimchi and fermented rice bran, but not for the production of yogurt because they generally do not grow in milk. The three strains of lactic acid bacteria described in this paper did not solidify milk, but \#4-2 and 8/11-3 strains grew in milk and reached a concentration greater than $1 \times 10^{7} \mathrm{cfu} /$ $\mathrm{mL}$. Fermented milk containing a minimum $8.0 \%$ milk solids-not-fat content should contain more than $1 \times 10^{7}$ $\mathrm{cfu} / \mathrm{mL}$ of lactic acid bacteria according to the Ministry of Health, Labor and Welfare in Japan (10). Therefore, these lactic acid bacteria are considered useful for manufacturing fermented beverages made from milk.

\section{References}

1. Ezendam J, van Loveren H. Probiotics: immunomodulation and evaluation of safety and efficacy. Nutr Rev. 2006; 64:114.

2. Saxelin M, Tynkkynen S, Mattila-Sandholm T, De Vos WM. Probiotic and other functional microbes: From markets to mechanisms. Curr Opin Biotechnol. 2005; 16:204-211.

3. Perdigón G, Fuller R, Raya R. Lactic acid bacteria and their effect on the immune system. Curr Issues Intest
Microbiol. 2001; 2:27-42.

4. Browne N, Heelan M, Kavanagh K. An analysis of the structural and functional similarities of insect hemocytes and mammalian phagocytes. Virulence. 2013; 4:597-603.

5. Imler JL. Overview of Drosophila immunity: A historical perspective. Dev Comp Immunol. 2014; 42:3-15.

6. Ishii K, Hamamoto H, Kamimura M, Sekimizu K. Activation of the silkworm cytokine by bacterial and fungal cell wall components via a reactive oxygen speciestriggered mechanism. J Biol Chem. 2008; 283:2185-2191.

7. Dhital S, Hamamoto H, Urai M, Ishii K, Sekimizu K. Purification of innate immunostimulant from green tea using a silkworm muscle contraction assay. Drug Discov Ther. 2011; 5:18-25.

8. Nishida S, Ono Y, Sekimizu K. Lactic acid bacteria activating innate immunity improve survival in bacterial infection model of silkworm. Drug Discov Ther. 2016; 10:49-56.

9. Kuda T, Kataoka M, Nemoto M, Kawahara M, Takahashi $\mathrm{H}$, Kimura B. Isolation of lactic acid bacteria from plants of the coastal Satoumi regions for use as starter cultures in fermented milk and soymilk production. LWT - Food Science and Technology. 2016; 68:202-207

10. Ministerial Ordinance on Milk and Milk products Concerning Compositional Standards, etc. (Ministry of Health and Welfare Ordinance No. 52, December 27, 1951).

(Received December 9, 2016; Revised January 30, 2017; Accepted February 2, 2017) 